\title{
CONF-9508251--1 \\ Evaluating Environmental Consequences of Producing Herbaceous Crops For Bioenergy
}

S.B. MCLaughIin

Biofuels Feedstock Development Program Environmental Sciences Division Oak Ridge National Laboratory

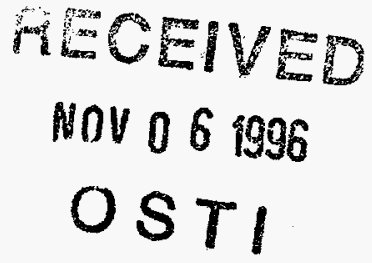

\section{Abstract}

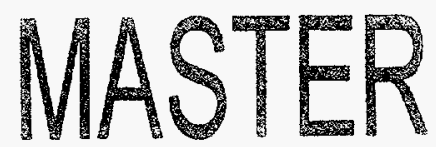

The environmental costs and benefits of producing bioenergy crops can be measured both in terms of the relative effects on soil, water, and wildife habitat quality of replacing alternate cropping systems with the designated bioenergy system, and in terms of the quality and amount of energy that is produced per unit of energy expended. While many forms of herbaceous and woody energy crops will likely contribute to future biofuels systems, The Department of Energy's Biofuels Feedstock Development Program (BFDP), has chosen to focus its primary herbaceous crops research emphasis on a perennial grass species, switchgrass (Panicum virgatum), as a bioenergy candidate. This choice was based on its high yields, high nutrient use efficiency, and wide geographic distribution, and also on its positive environmental attributes. The latter include its positive effects on soil quality and stability, its cover value for wildlife, and the lower inputs of energy, water, and agrochemicals required per unit of energy produced. A comparison of the energy budgets for corn, which is the primary current source of bioethanol, and switchgrass reveals that the efficiency of energy production for a perennial grass system can exceed that for an energy intensive annual row crop by as much as 15 times. In additions reductions in $\mathrm{CO}_{2}$ emissions, tied to the energetic efficiency of producing transportation fuels and replacing non-renewable petrochemical fuels, are very efficient with grasses. Calculated carbon sequestration rates may exceed those of annual crops by as much as 20-30 times, due in part to carbon storage in the soil. These differences have major implications for both the rate and efficiency with which fossil energy sources can be replaced with cleaner burning biofuels. Current research is emphasizing quantification of changes in soil nutrients and soil organic matter to provide understanding of the long term changes in soil quality associated with annual removal of high yields of herbaceous energy crops.

\section{DISTRIBUTION OF THS DOCUMENT $1 S$ UNLIETED}

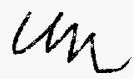




\section{DISCLAIMER}

This report was prepared as an account of work sponsored by an agency of the United States Government. Neither the United States. Government nor any agency thereof, nor any of their employees, makes any warranty, express or implied, or assumes any legal liability or responsibility for the accuracy, completeness, or usefulness of any information, apparatus, product, or process disclosed, or represents that its use would not infringe privately owned rights. Reference berein to any specific commercial product, process, or service by trade name, trademark, manufacturer, or otherwise does not necessarily constitute or imply its endorsement, recommendation, or favoring by the United States Government or any agency thereof. The views and opinions of authors expressed herein do not necessarily state or reflect those of the United States Government or any agency thereof. 


\section{DISCLAMMER}

Portions of this document may be illegible in electronic image products. Images are produced from the best available original document. 


\section{Overview}

The need to reduce national dependency on imported oils, and the opportunity to develop the nations' agricultural potential for producing high yielding crops as a renewable bioenergy supply have prompted significant national research on both the agricultural production and energy conversion technologies necessary to realize this potential (Wright, 1994 and Lynd et al, 1991). As with any new technological issue, a variety of potential environmental impacts must be considered in addressing the net benefits or risks of proceeding with development. A wide range of environmental issues related to biofuels development have been identified (OTA, 1993). These include potential changes in air quality, water availability and quality changes, and residue disposal associated with industrial aspects of biofuels production. In each of these areas there are potential benefits and risks to be considered. An important perspective for considering such risks and associated strategies to reduce them is weighing the environmental tradeoffs between biofuels technologies and the fossil fuel technologies they replace. A similar approach can also be applied to biofuels feedstock production in asking how dedicating land to feedstock production will alter impacts from current land use. There are three important considerations in making such an assessment:

1. The agronomic attributes of the bioenergy cropping system being considered, including specifically effects on soil and water quality

2. The net effect of any differences between (1) and the land use system it replaces, and

3. The quality and quantity of energy that is produced from the feedstock per unit of energy expended and per unit of environmental cost of the fossil energy it replaces.

After evaluating yield and agronomic data on 34 herbaceous candidate species, the BFDP at Oak Ridge National Laboratory (ORNL) selected a native perennial species, switchgrass, for further research and development as its primary herbaceous bioenergy candidate. This choice was made based both on the high yields and excellent versatility of switchgrass determined in early field trials, and on the many positive environmental attributes. This article focuses on the nature of those attributes, but, more importantly, on how those attributes relate to the third factor listed above: the net energy return and associated environmental benefits of bioenergy production from perennial grasses, such as switchgrass relative to annual row crops such as corn. 


\section{AGRONOMIC ATTRIBUTES OF SWITCHGRASS}

Switchgrass (Panicum virgatum) is a sod-forming, warm season grass, which was an important component of the native, highly productive North American Tallgrass Prairie (Weaver, 1968). Today switchgrass and some of the other native prairie grasses have become increasingly important as forage grasses in the Midwest, because of their capacity to grow during the hot summer months when water availability limits growth of most other grass and crop species (Moser and Voge1, 1995). Switchgrass has a geographical range that covers most of the US and portions of Canada and Central America (See Figure 1) and was found by early settlers in diverse habitats ranging from midwestern prairies to brackish marshes and open woods (Hitchcock, 1951). Its wide range and associated adaptability, high yields, and flexibility to be utilized both as a forage species and as a biofuel were among the main attributes in its selection by ORNL's Biofuels Feedstock Development Program (BFDP) as a model herbaceous crop (McLaughlin, 1992). Yields have been excellent averaging $11-22$ in unirrigated research plots, with a one year, single plot, maximum of $37 \mathrm{Mg} \mathrm{ha}^{-1}$. Additional considerations for selecting switichgrass were its positive environmental attributes, including low nutrient use, low pesticide requirements, and its perennial growth habit.

The perennial growth of warm season grasses is an extremely important aspect of their ecology and economics and essential to their role in soil conservation (McLaughlin et al., 1994). Once established, perennial grasses can be produced for many years without the annual replanting cycle that increases soil loss and degradation. The deep, well developed root systems of these grasses can result in standing pools of root biomass being comparable to that produced annually above ground (Anderson and Coleman, 1985). This "investment" of energy belowground has many benefits, including efficient acquisition of nutrients and water, a strong energy storage reserve, more stable yields during stress years, and finally, increased soil organic matter. This latter attribute is one of the keys to perennial grass contributions to soil conservation because it influences soil erosion, water and nutrient conservation, and runoff and losses of agricultural chemicals.

\section{Perennial Grasses and the CRP}

Soil erosion is a major problem influencing soil and water quality in agricultural areas around the world and in the US is considered a major threat to long term crop production (Larson et al., 1983). In the US alone, annual estimates of soil losses have been placed at $1-2$ billion tons per year (ASCE, 1977). At the time of a national survey of soil conservation needs in 1977 , approximately 72 million 
acres of US cropland was estimated to need erosion control (Shiflett and Darby, 1985). Poor agricultural practices, including annual row crop production on erosive soils, not only enhance losses of the more productive surface soils and associated nutrients, they deplete soil organic matter (SOM) through alterations in soil nutrient cycling.

The current rate of loss of soil organic matter (SOM) through annual row cropping in the United States has been estimated at 2.7 million metric tons per year (CAST, 1992). Loss of SOM can alter many important aspects of soil quality. Soil moisture holding capacity, soil density and aeration, and soil nutrient availability and conservation are among the essential properties controlled by SOM (Buckman and Brady, 1960).

Decades of annual row cropping in the Northern Plains have resulted in significant depletion of soil organic matter and soil nutrients on erosive soils (Aguilar et al., 1988). Congress established the Conservation Reserve Program (CRP) in 1985 as a means of protecting erodible cropland from continued depletion by agricultural production. The erosion limiting capacity of perennial grasses has resulted in their being planted on much of the 36 miliion acres of CRP land, established since 1985 to combat soil loss from the intense cultivation of annual crop production.

\section{SOIL CARBON DYNAMICS AND IMPORTANCE}

Recent studies by the Soil Conservation Service to examine changes in SOM during 5 years of perennial grass production on Conservation Reserve Program (CRP) lands indicate that perennial grasses added 1.1 tons*ha ${ }^{-1}$ of carbon to the upper $300 \mathrm{~cm}$ of mid-western soils (Gebhart et al, 1994). These additions replaced 23\% of the soil carbon lost during decades of prior tillage. The large standing pools of roots are a major source of this carbon, however both rhizosphere deposition and Eine root turnover, which may add up to $3 \mathrm{Mg} \mathrm{ha}^{-1} \mathrm{y}^{-1}$ (Lynch and Whipps, 1991), and active populations of soil microorganisms and invertebrates, which may total >4 MG/HA are important to soil carbon pools and to function of soil as a retentive nutrient cycling reservoir (Barnes and Taylor, 1985).

The addition of significant quantities of organic matter into soils by the prolific rooting systems of perennial grasses has many benefits from a soil conservation standpoint (Mclaughlin et al., 1994). These include improved soil structure, increased water-holding capacity and infiltration through structural and porosity changes, improved nutrient conservation and availability, and decreased soil erosion. The organic material containing soil carbon serves many roles ranging from providing nutrients as decomposition occurs, to enhancing the capacity of the soil to retain, and provide water and nutrients to plants. Ultimately availability of both 
existing and added water and nutrients to vegetation is enhanced by increasing organic matter in soils.

\section{ROLE OF SWITCHGRASS IN SOIL CARBON, EROSION, AND SEDIMENTATION CONTROL}

Recent studies within the Department of Energy (DOE) sponsored BFDP support the occurrence of improved soil quality under cropping regimes utilizing the high yielding switchgrass varieties being developed as biofuel candidates. Significant augmentation of soil organic matter was noted after only four years of production in Virginia (Hall, 1991). These increases can be attributed to very high root mass which, in an ongoing study at Auburn University (Bransby et al., 1994), have totalled almost 8 metric tons per hectare (MTH) in just the top $75 \mathrm{~cm}$. With Alamo switchgrass, over $4 \mathrm{MTH}$ was found just in the $0-15 \mathrm{~cm}$ depth interval. The maximum rooting depth of switchgrass in natural prairie stands ranges from 2.6 to $3.7 \mathrm{~m}$, and annual belowground production of prairie ecosystems is frequently two to four times aboveground production (Risser et al., 1981). Grazing apparently stimulates belowground production.

The contrasts in soil erosion between perennial grasses and cultivated row crops, such as corn, which figures prominently in current ethanol production, are striking and have significant economic and ecological implications. Reductions in soil erosion properties under grass cultivation are well documented. Erosion losses associated with corn cultivation in Iowa, for example, were approximately 70 times greater than for production of grasses on similar land (Shiflet and Darby, 1985). During heavy rains soil losses from row cropped fields can exceed losses from grasslands by more than 200 times as shown for several locations in Table 1. Significant differences in runoff accompanied these enhanced soil losses. More modern reduced tillage methods, currently used on about 35\% of the corn produced in the U.S., can substantially reduce erosion rates (Seta et al., 1993).

Both the quantity of chemicals used to maintain production of grasses and the fate of those chemicals are expected to differ markedly with perennial grass production compared to that experienced historically for row crop production. Annual rates of nitrogen use, for example, are typically about half those required for corn production (70$100 \mathrm{~kg} / \mathrm{ha}$ compared to $140-280 \mathrm{~kg} / \mathrm{ha})$. In addition, switchgrass normally requires herbicide use only during the establishment year of what is anticipated to be at least a 10 year growth cycle, whereas corn and other annual crops require annual application. The costs of these additional chemicals must be included both in economic production costs to the farmer, and also in the ecolgical costs of increased rates of infiltration of chemicals into groundwater and runoff into streams.

Graham and Downing (1993) have evaluated regional aspects 
of replacing annual crops in western Tennessee with switchgrass for energy production. Using fertilizer application rates, crop use, land quality, and erosion models, they projected improved water quality associated with reduced chemical contributions to groundwater and reduced soil erosion. In addition reduced evapotranspiration was predicted based on the high water use efficiency of switchgrass compared to other grasses and annual crops (Stout et al., 1988).

Decreased runoff of agricultural chemicals with conversion to switchgrass production was not considered in this simulation, but may add significantly to the environmental benefits noted. On a national scale the United States loses approximately $\$ 18$ billion in fertilizer nutrients to soil erosion (NRC, 1993), so one should expect agricultural chemical inputs to aquatic systems also to be large.

In addition to reducing the effects of soil erosion in agricultural fields under cultivation, there is evidence that warm season grasses, such as switchgrass can play an important role in stabilizing soil along streams and wetlands. This attribute can be attributed both to growth characteristics, the density of stems and roots, which promote soil stability, and to its tolerance of periodic flooding. Studies to evaluate the capacity of various grass species to withstand flooding indicate that switchgrass has a strong tolerance of flooding and can withstand continuous immersion for 30-60 days (Gamble and Rhodes, 1964). In Missouri, switchgrass was found to have survived the severe 1993 midwestern flood with minimum damage to the grass stands and very effective control of levee deterioration from flood wash (Missouri, Department of Conservation, 1994). In addition, the capacity of forage grasses to increase soil stability and reduce overland flow of runoff waters from agricultural fields has contributed to their value as a conservation cover to retard sedimentation of wetlands adjoining erosive agricultural fields (Kruse, 1994).

\section{NET ENERGY RETURNS OF SWITCHGRASS}

An important measure of the environmental benefits of energy crops is the extent to which they can offset the environmental costs of extracting and burning fossil fuels. The net benefits of replacing fossil fuels with biofuels will depend not only on the energy contained in the biomass, but also on the energy required to grow the crop and convert it to a usable energy form. McLaughlin et al. (1996) have developed energy budgets for corn and switchgrass to contrast differences in both the net energy returned and the net change in $\mathrm{CO} 2$ emissions achieved by growing each crop type for renewable energy. Results are summarized in Tables 2 and 3 .

Gains in net energy returns from perennial grass production are derived from reduced energy investments at all steps of the crop production/conversion pathway leading to ethanol, formation (Table 2). This includes reduced energy 
required for agricultural production, increased energy in the biomass produced, and reduced energy to process the biomass into ethanol (Mclaughlin et al., 1996). The net effect of these differences is that, $55 \%$ more ethanol energy can be produced per hectare growing switchgrass than with an annual crop like corn. The net energy gain, which is strongly influenced by the low energy requirements of switchgrass, is even greater, 15 times higher for switchgrass compared to corn.

Calculations of net carbon gain for switchgrass vs corn produce similar large differences in the capacity of the ethanol produced to offset the $\mathrm{CO} 2$ emissions of the gasoline that it replaces (Table 3). The net carbon dioxide budget is based on the amount of fossil fuel consumed in producing the crop and the total amount of fossil fuel that can be replaced with ethanol produced per unit of land area. The combination of lower energy requirements to both produce and convert switchgrass to ethanol, result in about 20 times higher $\mathrm{CO}_{2}$ emissions savings with switchgrass compared to corn (Mclaughlin et al.,1995). Where switchgrass production replaces annual row cropping these gains may be increased even further due to increases in soil carbon storage belowground.

\section{INFORMATION NEEDS}

The environmental issues discussed in this paper have been largely the positive soil conservation attributes associated with production of switchgrass and other forage grasses. The CRP experience has provided valuable information in this area. Energetic and carbon budgets have been derived Erom field trial data, for production economics, and from bench-scale studies of conversion of switchgrass to ethanol. It should be noted at this stage, that there are no large, commerical scale plantings of switchgrass, and no production facilities are currently using large amounts of switchgrass. Our short-term studies indicate that soil carbon can be significantly improved with perennial grass production. Tests to date with diverse soil types in both Virginia and Texas support these findings, however the extent and regional significance of such changes has yet to be determined and will await an expanded network of test sites to determine longer term levels of soil improvement for various soil types and previous land use characteristics.

There are some additional environmental information needs that will be important to address if switchgrass is to significantly expand as an energy crop. Principle areas of need are the development and licensing of appropriate pesticides for crop management and developing harvesting strategies which consider both yield and wildlife use of bioenergy stands. Tests of herbicides, and possibly insecticides, to aid in weed and insect control during the critical establishment year is currently a part of the DOE BFDP field trial program. Another aspect of that program is 
development of appropriate cutting strategies to maximize yield potential. Both two and one-cut harvest systems are being evaluated, including leaving the stand until after the first frost. Single-cut systems, pose minimum danger to nesting birds, while the timing of the first cut of two-cut systems may impact some birds in some areas. Effects of bioenergy crops on wildlife are discussed elsewhere in this issue (Christian et al, 1996).

\section{CONCLUSIONS}

There are many obvious environmental benefits of increased utilization of switchgrass as a renewable energy crop. We have provided a brief summary here of three of the most significant and most obvious of these. They include, improved soil conservation, improved energy gain, and improved reductions in emissions of carbon dioxide. Certainly, all of the environmental issues associated with the processes of producing and converting energy crops to fuel and electricity have not yet been quantified in final detail. Process engineering is proceeding to minimize other environmental risks associated with biofuel conversion and combustion processes and it is reasonable to anticipate that environmental risks will be far lower than for current technologies based on fossil fuels. In the meanwhile, the soil conservation benefits, gains in energy return, and reductions in $\mathrm{CO} 2$ emissions reduction discussed above have important ecological and economic dimensions that are known to be positive. These environmental benefits should provide an important impetus for moving forward with larger scale commercialization. The gains in net energy return are particularly important as a measure not only of the rate at which energy self reliance can be increased, but also in terms of reductions in a wide range of environmental costs associated with the aquisition and combustion of fossil fuels.

\section{ACKNOWLEDGEMENTS}

Research sponsored by the Biofuels Systems Division, U.S. Department of Energy, under contract DE-AC05-960r22464 with Martin Marietta Energy Systems, Inc.

\section{LITERATURE CITED}

Aguilar, E.F. Kelly, and R.D. Heil. 1988. Effects of cultivation on soils in northern great plains rangeland. Soil Sci. Soc. Am. J. 52: 1081-1085.

Anderson, D.W. and D.C. Coleman. 1985. The dynamics of organic matter in grassland soils. 1985. J. Soil and Water Conservation.40: 211-216. 
ASCE. 1977. In Froc. Task Committee of Agricultural Runoff Drainage of Water Quality of the Irrigation Drainage Division. American Society of Civil Engineering. Irrigation Drainage 103(IR4): $475-95$.

Barnes, R.F. and T.H. Taylor. 1985. Grassland agriculture and ecosystem concepts. P 12-20. In M.E. Heath, R.F. Barnes, and D.S. Metcalfe, Forages: The Science of Grassland Agriculture, Iowa State Univ Press

Bransby, D.I., R.H. Walker, D.W. Reeves, G.L. Mullins, and M.S. Miller. 1994 Development of Optimal Establishment and Cultural Practices for Switchgrass as an Energy Crop. 1993 Annual Report to Oak Ridge National Laboratory Biofuels Feedstock Development Program.

Browning, G.M.1973. In forages: The Science of Grassland Agriculture, 3rd ed. Ames: Iowa State Univ. Press. Source of data in Table 1 (as cited in Shifflet, T.N. and Darby, G.M., 1985)

Buckman, H.O. and N.C. Brady. 1960. The Nature and properties of soils. McMilian Co., NY, 567.

CAST.1992. Preparing U.S. agriculture for global climate change. Council for Agric. Sci. and Tech. Report 119. 93 p.

Gamble, M.D. and E.D. Rhodes, 1964. Effects of shoreline fluctuations on grasses associated with upstream flood prevention and watershed protection. Agronomy J. 56: 21-23

Gebhart, D.L., H.B. Johnson, H.S. Mayeux, and H.W. Polley. 1994. The CRP increases soil organic carbon. J. Soil Water Conserv. $49: 488-492$.

Graham, R.L. and M. Downing. 1993. Renewable biomass energy: Understanding regional scale impacts. p 1566-1581. In Proc. First Biomass Conf. Amer. Aug 30-Sept.2, Burlington, VT.

Hall, D.S. 1991. Soil-Plant Root Relationships of Herbaceous Biomass Crops Grown on the Piedment of Virginia. MS Thesis, Virginia Polytechnic Institute and State University, Blacksburg, VA.

Hitchcock, S.S. 1951. Manual of grasses of the United States. USDA misc.Pub. 200, 2nd edit.

Kruse, A.D.1994. CRP and its long range potential for wetland resource, environmental easements, and conservation easements in the Northern Great Plains. P29 (abstract) in Rangelands Diversity and Responsibility. 1994 Mgt. Soc. Range Mgt., Feb 13-14, Colorado Springs, CO. 
Larson, W.E., F.J. Pierce, and R.H. Dowdy. The threat of soil erosion to long term crop production. Science.219: 458-464.

Lynch, J.M. and J.M. Whipps. 1991. Substrate flow in the rhizosphere. P 15-24 in D.I. Keister and P.B. Cregan, eds. The Rhizosphere and Plant Growth. Kluwer Acad. Pub.

Lynd, IJ., J.H. Cushman, R.J. Nichols, and C.F. Wyman.1991. Euel ethanol from cellulosic biomass. Science 231: 1318-1323. MCConnel, S.G. and M.L. Quinn. 1988. Soil productivity of four land use systems in Southeastern Montana. Soil Sci. Soc. Amer. J. $53: 500-506$.

McLaughlin, S.B., 1992. New switchgrass biofuels research program for the Southeast. $p 111-115$ in Proceed. Ann. Auto. Tech. Dev. Contract. Coord. Mtng., Dearborn, MI. Nov.2-5, 1992 .

McLaughlin, S.B., D.I. Bransby, and D. Parrish. 1994. Perennial Grass Production for Biofuels: Soil Conservation Considerations. PP In Bioenergy 94. Proceedings Reno NV, Oct, 1994 .

McLaughlin, S.B., M. Walsh, D. Tyndall, M.Downing, M. Sanderson, A. Weislogel, D. Wolf, S. Wullschleger, K. Vogel. Power in Prairie Grasses: An Economic and Ecological Perspective. Manuscript to be submitted to Biomass and Bioenergy, Fall, 1996.

Moser, I.E. and K.P. Vogel.1995. Switchgrass, Big Bluestem, and Indiangrass. P409-420. In. Forages Vol 1, An Introduction to Grassland Agriculture. R.f. Barnes, D.A. Miller, C.J. Nelson (Eds), Iowa State University Press.

National Research Council.1993. Vetvier Grass. A Thin Green Line Against Erosion. Nat. Acad. Press, Wash., D.C.

OTA, 1993. Fotential Environmental Impacts of Bioenergy Crop Production. Office of Technology Assessment. U. S. Congress. $71 \mathrm{P}$.

Risser, P.G., E.C. Birney, H.D. Blocker, S.W. May, W.J. Parton, and J.A. Wiens. 1981. The True Prairie Ecosystem. US/IBP Synthesis Series 16. Hutchinson Ross Pub. 557 p.

Seta, A.K., R.I. Blevins, W.W. Frye, and B.J. Barfield. 1993. Reducing soil erosion and agricultural chemical losses with conservation tillage. J. Env. Qual. 22:661-665.

Shifflet, T.N. and Darby, G.M.1985. Forages and Soil Conservation. pp $21-32$ in Forages: The Science of Grassland 
Agriculture, M.E. Heath, R.F. Barnes, and D.S. Metcalfe eds., Iowa State Univ. Press.

Stout, W.L., G.A. Jung, J.A. Shaffer, and R. Estepp. 1986. Soil water conditions and vield of tall fescue, switchgrass, and Caucasian bluestem in Appalachian Northeast. J. Soil and water Conservation. 41: 184-186.

Stubbendieck, J., S.L.Hatch, and C.H. Butterfield. 1981. North American Range Plants. Univ. Nebraska Press, Lincoln, NE.493 pp.

Tyson, K.S., C.J. Riley, K.K. Humphreys. 1994. Fuel Cycle Evaluations of Biomass-Ethanol and Reformulated Gasoline. Vol.I. National Renewable Energy Laboratory, Golden, Co. NREL$T P-463-4950$

Weaver, J.E. 1968. Prairie Plants and Their Environment. A Fifty Year Study in the Midwest. Univ. of Nebraska Press, Lincoln, NE, 276p

Wright, L.L. 1994. Production technology status of woody and herbaceous crops. Biomass and Bioenergy 6: 191-210. 
Figure 1. Switchgrass is broadly adapted to environmental conditions and occurs across much of North America, in addition to being an important ecological component of native grassland ecosystems. Map developed from data in Riser et al, I991 and Stubbendieck et al, 1981.

Table 1. Historical data on the effects of row crops and grassland sod on runoff and erosion demonstrate the effectiveness of grass cover in reducing erosion ( Source Browning, 1973).

Table 2 . Contrasts between net energy budgets of switchgrass and corn in production of ethanol (After McLaughlin et al., 1995)

Table 3 . Contrasts between switchgrass and corn in rate of reduction of $\mathrm{CO} 2$ emissions (After McLaughlin et al., 1995). 


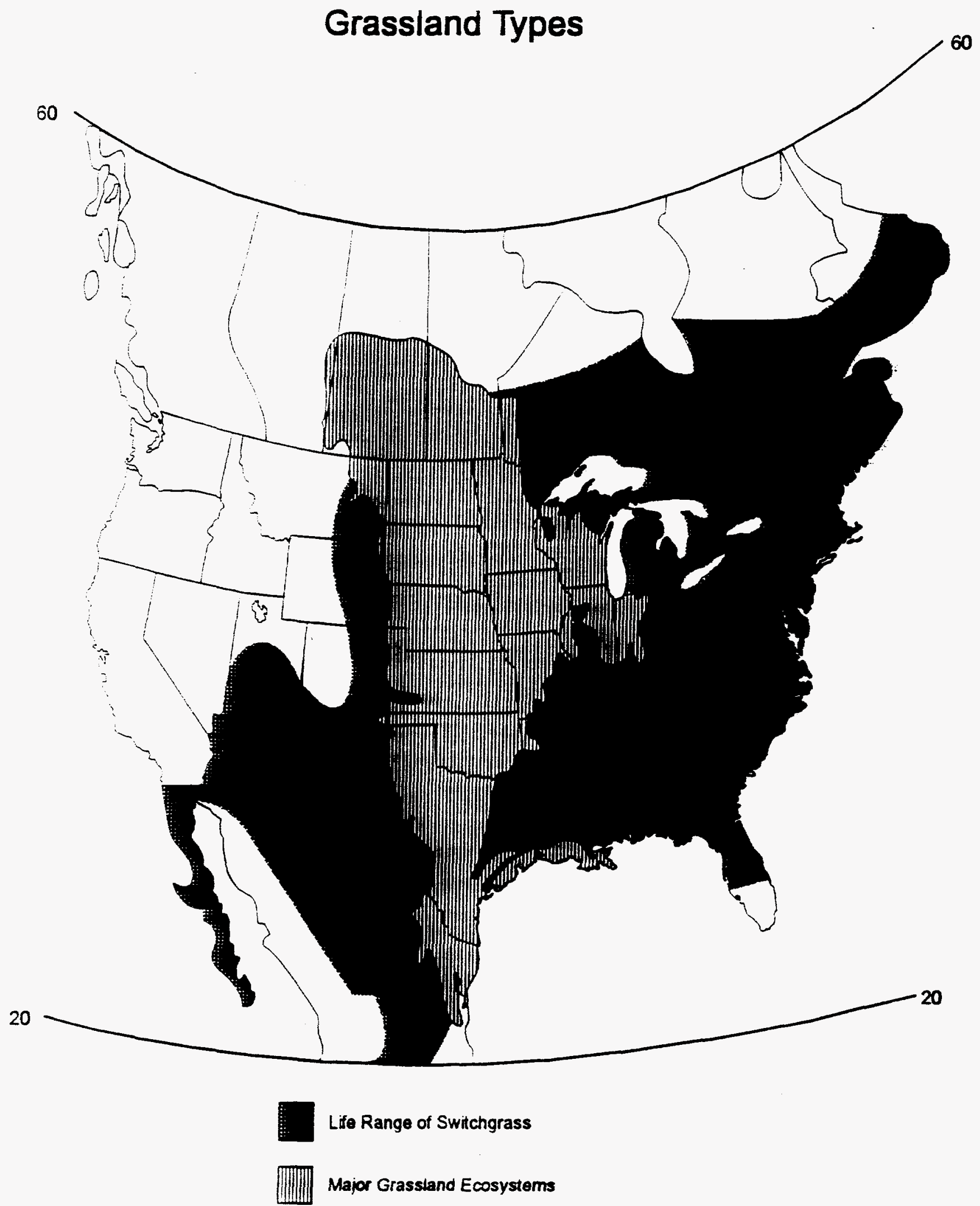


Table 1. Effect of row and sod crops on runoff and erosion

\begin{tabular}{|c|c|c|c|c|c|c|}
\hline \multirow[b]{2}{*}{ Soil type } & \multirow[b]{2}{*}{ Location } & \multirow[b]{2}{*}{$\begin{array}{l}\text { Slope } \\
(\%)\end{array}$} & \multicolumn{2}{|c|}{ Soil loss (t/ha) } & \multicolumn{2}{|c|}{ Runoff $(\%)$} \\
\hline & & & $\begin{array}{l}\text { Row } \\
\text { crop }\end{array}$ & Sod & $\begin{array}{l}\text { Row } \\
\text { crop }\end{array}$ & Sod \\
\hline Marshall silt loam & Iowa & 9.0 & 85.6 & .067 & 18.7 & 1.3 \\
\hline Shelby loam & Missouri & 8.0 & 114.1 & .359 & 27.1 & 8.1 \\
\hline Muskingum silt loam & Ohio & 12.0 & 222.6 & .045 & 40.3 & 4.8 \\
\hline $\begin{array}{l}\text { stepnenvile nne sanay } \\
\text { loam }\end{array}$ & Oklahoma & 7.7 & 42.4 & .045 & 12.5 & 1.0 \\
\hline Cecil clay loam & N. Carolina & 10.0 & 70.0 & .695 & 12.1 & 1.9 \\
\hline Kervin fine sandy loam & Texas & 8.7 & 53.8 & .179 & 19.9 & 1.0 \\
\hline $\begin{array}{l}\text { Kervin fine sandy loam } \\
\text { Nacogdoches sandy }\end{array}$ & Texas & 16.5 & 137.0 & .011 & 14.4 & 0.3 \\
\hline loam & Texas & 10.0 & 14.6 & .011 & 13.9 & 0.3 \\
\hline Austin clay & Texas & 4.0 & +6.2 & .045 & 13.6 & 0.05 \\
\hline Austin black clay & Texas & 2.0 & 17.5 & .179 & 10.5 & 1.2 \\
\hline Fayette silt loam & Wisconsin & 16.0 & 250.4 & .224 & 29.2 & 0.55 \\
\hline
\end{tabular}

${ }^{a}$ Row crop was continuous corn on Marshall, Shelby, Muskingum, Fayette, and Austin soils. Cotton was grown on Stephenvile, Cecil. Kervin, and Nacogdoches soils. The sod crop was either Kentucky bluegrass or bermudagrass. Modern no-till and minimum-till techniques currently used on approximatety $35 \%$ of corn currently being produced can substantially reduce erosion rates from these rates that were determined for conventionally tilled fields.

Source: Browning, G.M. 1973. In Forages: The Science Grassland Agriculture. 3d ed. Iowa State Univ. Press, Ames, LA. 
Table 2. Comparative energy flow in producing ethanol from switchgrass and corn (After McLaughlin et al., 1995)

\begin{tabular}{|l|c|c|}
\hline \multirow{2}{*}{\multicolumn{1}{|c|}{ Process }} & \multicolumn{2}{|c|}{ Gigajoules per Hectare per Year } \\
\cline { 2 - 3 } & Corn $^{1}$ & Switchgrass $^{1}$ \\
\hline Crop Production & 18.9 & $17.8(12.8)$ \\
\hline Biomass Energy $^{2}$ & 149.5 & 220.2 \\
\hline Energy Ratio R1 $^{3}$ & 7.9 & $12.3(17.2)$ \\
\hline Ethanol Production $^{+}$ & 47.9 & 10.2 \\
\hline Energy in Ethanol $^{5}$ & 67.1 & 104.4 \\
\hline Total Energy Ratio R2 $^{\circ}$ & 1.21 & 4.43 \\
\hline Net Energy Gain & $21 \%$ & $343 \%$ \\
\hline
\end{tabular}

' Budget data for production and processing corn are from Shapouri, et al., 1995. Production data are adjusted for $0.73 \mathrm{GJ}^{*}$ ha $\mathrm{a}^{-1}$ machinery production costs. Switchgrass data include costs of on-farm storage and secondary handling or direct transfer to buyer (in parentheses.)

- Yields assumed were $13.5 \mathrm{Mg}^{*}$ ha ${ }^{-1}$ for switchgrass and $301 \mathrm{Bu}^{*} \mathrm{ha}^{-1}$ for corn. Corn biomass energy includes $18.9 \mathrm{Gj}^{*} \mathrm{ha}^{-1}$ of energy in corn fiber and no credit for stover.

${ }^{3}$ Biomass energy/production energy

${ }^{+}$Includes processing and distribution energy. Switchgrass data are derived from analyses of the saccharification and fermentation processes for ethanol production at the National Renewable Laboratory (Tyson et al.. 1994)

E Ethanol yields are $2963 \mathrm{I}^{*}$ ha $\mathrm{a}^{-1}$ for corn and $4487 \mathrm{I}^{*}$ ha ${ }^{-1}$ for switchgrass with ethanol energy of $23.3 \mathrm{~kJ} * \mathrm{~L}^{-1}$ used to calculate product energy.

- Total output energy /total input energy (processing, production. and distribution energy). Out Output energy includes allowance of $14.2 \mathrm{GJ}^{*} \mathrm{ha}^{-1}$ credits for coproducts for corn and 19.8 $\mathrm{GJ}^{*} \mathrm{ha}^{-1}$ for combustion of lignin from switchgrass 
Tabie 3. Comparative carbon flow in producing ethanol from switchgrass and corn (after McLaughlin et. al., 1995)

\begin{tabular}{|l|c|c|}
\cline { 2 - 3 } \multicolumn{1}{c|}{} & \multicolumn{2}{c|}{ Kg Carbon Per Hectare } \\
\hline A. Production Costs & Corn & Switchgrass \\
\hline B. Fuel Replacement & 1492 & 598 \\
\hline C. Net Combustion Savings & 1578 & 2480 \\
\hline D. Soil Carbon Storage & 86 & 1882 \\
\hline E. Total Carbon Reduction & - & 1100 \\
\hline
\end{tabular}

Includes annual agricultural production. chemical processing, and distribution energy costs ${ }^{2}$ Replacement of gasoline at $19.94 \mathrm{KgC} / \mathrm{GJ}$ with ethanol. Coproduct credits were allowed for both corn $\left(247 \mathrm{KgC}^{*} \mathrm{ha}^{-1}\right)$ and switchgrass $\left(437 \mathrm{KgC}^{*} \mathrm{ha}^{-i}\right)$ based on energy equivalence of those coproducts.

${ }^{3}[\mathrm{~B}]-[\mathrm{A}]$

${ }^{+}$Assumes $1100 \mathrm{KgC}^{*} \mathrm{ha}^{-1 *} \mathrm{y}^{-1}$ gain in soil organic carbon on land depleted by row croping ${ }^{5} \mathrm{C}+\mathrm{D}$ 